\title{
The Self-Concept Of Young Married With Cage Friends
}

\section{Konsep Diri Remaja Menikah Muda Dengan Teman Sebaya}

\author{
Okta Asmita1); Sapta Sari ${ }^{2)}$; Sri Narti ${ }^{2)}$ \\ 1, 2) Department of Communication, Faculty of Social Sciences, Universitas Dehasen Bengkulu \\ Email: oktaasmita94@gmail.com
}

\begin{abstract}
How to Cite :
Asmita, O., Sari, S., Narti, S. (2021). The Self-Concept Of Young Married With Cage Friends. Sengkuni Journal: Social Sciences and Humanities Vol. 2 No. 12021 page: 62-69. DOI: https://doi.org/10.37638/sengkuni.2.1.62-69
\end{abstract}

\section{ARTICLE HISTORY}

Received [03 May 2021]

Revised [06 June 2021]

Accepted [12 June 2021]

\section{KEYWORDS}

Self-Concept, Adolescents,

Young Married, Peers
This is an open access article under the $\underline{C C-B Y-S A}$ license

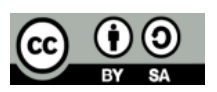

\begin{abstract}
ABSTRAK
Fenomena pernikahan dini merupakan persoalan yang banyak terjadi dan dianggp biasa oleh remaja di kabupaten Bengkulu Tengah yang termasuk dalam kategori tiga besar kasus pernikahan usia dini di provinsi Bengkulu tahun 2019. Tujuan penelitian ini adalah untuk mengetahui konsep diri remaja menikah muda dengan teman sebaya di desa Kertapati Mudik. Penelitian ini menggunakan metode penelitian deskriftip kualitatif dengan tehnik pengumpulan data melalui observasi, wawancara dan dokummentasi. Teori yang digunakan adalah William Brooks (2017: 108) yaitu faktor-faktor yang mempengaruhi konsep diri seseorang. Hasil penelitian menunjukkan bahwa konsep diri remaja menikah muda dengan teman sebaya terbentuk melalui yang pertama pandangan mereka terhadap dirinya sendiri yang menganggap bahwa mereka sudah siap menikah meskipun umur mereka masih muda, hal ini dibuktikan adanya perubahan sikap yang menyesuaikan peran dan status mereka sudah berumah tangga. Kedua, reaksi dan respon dari orang lain dapat membentuk konsep diri pasangan menikah muda berkembang melalui interaksi pasangan suami istri dengan masyarakat. Konsep diri terbentuk dari proses belajar dengan memahami reaksi dan respon dari tetangga, kepala desa dan ketua BMA sehingga pasangan suami istri ikut bersosialisasi dan berpartisipasi dalam masyarakat. Ketiga, konsep diri pasangan menikah muda terbentuk dari peran mereka sebagai suami istri dalam rumah tangga memberikan pengaruh dalam pembentukan konsep diri yang positif, hal ini dipengaruhi juga peran orang tua, teman sebaya dan lingkungan. Jadi pada awalnya konsep diri remaja menikah muda dengan teman sebaya yaitu konsep diri negative namun berkembang setelah menikah menjadi konsep diri positif karena mereka mampu menyelesaikan masalah mereka sendiri dan sudah berpartisipasi dilingkungannya.
\end{abstract}

\section{ABSTRACT}

The phenomenon of early marriage is a problem that often occurs and is considered normal by adolescents in Central Bengkulu district which is included in the category of the top three cases of early marriage in Bengkulu province in 2019. The purpose of this study was to determine the self-concept of teenagers marrying young with peers in Kertapati village. Homecoming. This study uses descriptive qualitative research methods with data collection techniques through observation, 
interviews and documentation. The theory used is William Brooks (2017: 108), namely the factors that influence a person's self-concept. The results of the study show that the self-concept of adolescents who marry young with their peers is formed through their first view of themselves which assumes that they are ready to marry even though they are still young, this is evidenced by changes in attitudes that adjust their roles and status as married. Second, reactions and responses from other people can shape the self-concept of young married couples developing through the interaction of married couples with the community. The self-concept is formed from the learning process by understanding the reactions and responses of neighbors, village heads and BMA leaders so that married couples participate in socializing and participating in society. Third, the self-concept of young married couples formed from their roles as husband and wife in the household has an influence in the formation of a positive self-concept, this is also influenced by the role of parents, peers and the environment. So at first the self-concept of teenagers marrying young with peers is a negative self-concept, but it develops after marriage into a positive self-concept because they are able to solve their own problems and have participated in their environment.

\section{PENDAHULUAN}

Pernikahan merupakan prosesi sakral dalam kehidupan manusia. UndangUndang Nomor 1 Tahun 1974 Pasal 1 menyatakan bahwa pernikahan adalah ikatan lahir batin antara seorang pria dan seorang wanita sebagai suami istri dengan tujuan membentuk keluarga atau rumah tangga yang bahagia dan kekal berdasarkan Ketuhanan Yang Maha Esa. Pada Pasal 2 menyatakan bahwa pernikahan dinyatakan sah apabila dilakukan menurut hukum masing-masing agama dan kepercayaannya, serta tiap-tiap pernikahan dicatat menurut peraturan perundang-undangan yang berlaku (https://www.jogloabang.com/pustaka/uu-16-2019-perubahan-uu-1-1974-perkawinan). Di antara banyaknya bentuk pernikahan yang terjadi, terdapat fenomena pernikahan dini pada kalangan remaja. Pada hakekatnya pernikahan dini adalah sebuah bentuk ikatan atau pernikahan yang salah satu atau kedua pasangan berusia di bawah 18 tahun atau sedang menempuh pendidikan sekolah dan masih termasuk dalam kategori usia remaja (UU No. 23 Pasal 81 Ayat 2 Tahun 2002).

Sebuah pernikahan disebut pernikahan dini, jika kedua atau salah satu pasangan masih berusia di bawah 18 tahun yakni masih berusia remaja. Standar usia pernikahan menurut undang-undang yaitu pada wanita 21 tahun dan pria 21 tahun. Undang-undang perkawinan No 1 tahun 1974 ternyata tidak kaku dan cukup memberikan ruang toleransi, hal ini bisa terlihat dari pasal 7 ayat (2) dalam hal penyimpangan terhadap ayat (1) pasal ini dapat meminta dispensasi kepada Pengadilan atau pejabat lain yang ditunjuk oleh kedua orang tua pihak pria ataupun pihak wanita. Bagi umat Islam tentu orang tua/wali para catin harus mengajukan ijin dispensasi nikah kepada Pengadilan Agama atau Mahkamah Syar'iyah kabupaten didaerah catin tinggal. Setelah ijin keluar baru akad nikah bisa dilaksanakan. Ijin tersebut akan dijadikan dasar oleh PPN/Penghulu serta akan mencantumkannya dalam lembaran NB daftar pemeriksaan nikah poin II Calon Suami No 16 baris 33,34 dan poin III Calon Isteri No.16 baris 71,72. 
Dengan demikian pernikahan yang masih dibawah umur atas ijin pengadilan menjadi sah dan berkekuatan hukum.

Menurut BKKBN pernikahan dini sering kali berpotensi pada kasus perceraian, hal ini disebabkan kurangnya kesiapan mental dan emosional pasangan yang terpaksa menikah karena kehamilan di luar nikah. Para pasangan tersebut awalnya tidak menyebutkan bahwa pernikahannya dilatar belakangi adanya kehamilan di luar nikah, namun seiring berjalannya waktu, fakta-fakta tersebut akhirnya terungkap. Hal ini disebabkan atas ketidaksiapan fisik dan mental para pasangan yang terpaksa menikah karena desakan tersebut. Akibatnya, selama berumah tangga, kedua pasangan tidak bisa memenuhi tanggung jawabnya masing-masing, lantas memicu berbagai pertengkaran bahkan tindakan kekerasan dalam rumah tangga baik kekerasan kepada pasangan maupun kepada anak, dan dalam perkembangannya, pernikahan dini akan membawa masalah psikologis yang besar dikemudian hari karena pernikahan tersebut. Fenomena pernikahan dini ini merupakan suatu persoalan yang banyak terjadi diberbagai tempat di tanah air. Millennium Development Goal's (MDG's) Indonesia 2007 yang diterbitkan oleh Bappenas (Badan Pengawasan Nasional) menyebutkan, bahwa Penelitian Monitoring Pendidikan oleh Education Network for Justice menemukan $28,10 \%$ remaja menikah pada usia di bawah 18 tahun. Mayoritas dari mereka adalah perempuan yakni sebanyak 76,03\%, dan laki-laki sebesar 58,31\%. Angka tersebut sesuai dengan data dari BKKBN yang menunjukkan tingginya pernikahan di bawah usia 16 tahun di Indonesia, yaitu mencapai $25 \%$ dari jumlah pernikahan yang ada. Bahkan di beberapa daerah persentasenya lebih besar, seperti Kalimantan Selatan 35,48\%, Jambi $30,63 \%$, Jawa Barat 36\%, dan Jawa Tengah 27,84\%.

Demikian juga temuan Komisi Perlindungan Anak Indonesia (KPAI) di Kawasan Pantura, pernikahan anak mencapai $35 \%$, dan $20 \%$ di antaranya dilakukan pada usia 911 tahun. Sedangkan di Kota Bengkulu menurut BKKBN dan RPJM tahun 2019 menunjukkan ada peningkatan pernihakan usia muda sebesar $6,1 \%$. Masih banyak anak di Provinsi Bengkulu belum lepas dari belenggu perkawinan usia dini. Berdasarkan data BKKBN Provinsi Bengkulu (2019), Kabupaten Bangkulu tengah masuk dalam kategorik 3 besar kasus pernikahan usia dini. Angka tertinggi di Kabupaten Mukomuko 32,83\%, seluma 30,83\% dan Bengkulu tengah 29,12\%. Di kabupaten Bengkulu Tengah sendiri pernikahan usia remaja menunjukkan angka persentase yang cukup tinggi.

Usia remaja sendiri dibagi menjadi dua periode yaitu remaja awal dan remaja akhir. Adapun usia remaja awal (usia 12 tahun) dan remaja akhir (21 tahun) masa remaja sebagai periode yang penting dalam perkembangan fisik dan psikis yang sama cepat juga memerlukan remaja untuk menyesuaikan diri didalam sikap dan mental remaja. Hal ini bahwa bekas-bekas pada masa kanak-kanak akan sangat mempengaruhi remaja nantinya, yang menyebabkan remaja sulit mengatasi masalahnya, dikarenakan adanya perubahan masa tumbuh kembang anak yaitu dari masa kanak-kanak ke masa remaja melalui pembentukan proses belajar remaja (Rahmawati, 2017: 56).

Konsep diri adalah merupakan pandangan seseorang tentang diri sendiri yang menyangkut perasaan, pikiran, maupun perilaku sehingga individu dapat mengolah informasi tersebut dan dapat memutuskan mengambil suatu tindakan yang akan dilakukan (Agus M. Hardjana, 2019:27). Konsep diri dimulai di lingkungan keluarga (oleh orang tua) dalam perkembangannya dapat lebih dimantapkan atau diubah". Dari uraian tersebut dapat disimpulkan bahwa perlakuan-perlakuan dari keluarga baik fisik maupun nonfisik dapat mempengaruhi konsep diri anak sehingga dapat berdampak tidak baik bagi pembentukan konsep dirinya. Misalnya, anak yang dididik oleh orang tua dengan keras hal ini dapat menyebabkan anak menjadi anak yang pemarah, keras. Perkembangan konsep diri dapat terjadi secara terus menerus dan berdasarkan pengalaman yang dimiliki remaja. Menurut penulis konsep diri merupakan seperti apa 
seseorang melihat dirinya, sejauh mana seseorang mengenal dirinya sehingga seseorang tersebut dapat memutuskan apa yang akan dia lakukan.

\section{LANDASAN TEORI}

\section{Konsep Diri, Remaja, Teman Sebaya}

Konsep diri adalah pandangan seseorang tentang dirinya sendiri yang menyangkut apa yang ia ketahui dan ia rasakan tentang perilakunya. Isi pikiran dan perasaan, serta bagaimana perilakunya tersebut berpengaruh terhadap orang lain. Konsep diri yang dimaksud adalah bayangan seseorang tentang keadaan dirinya sendiri pada saat ini dan bukanlah bayangan ideal dari dirinya sendiri sebagaimana yang diharapkan atau yang disukai oleh individu bersangkutan. Konsep diri berkembang dari pengalaman seseorang tentang berbagai hal mengenai dirinya sejak kecil. Terutama yang berkaitan dengan perlakuan orang terhadap dirinya (Djaali, 2013: 34).

Konsep diri pada dasarnya merupakan suatu skema, yaitu pengetahuan yang terorganisasi mengenai sesuatu yang kita gunakan untuk menginterpretasikan pengalaman. Dengan demikian konsep diri adalah skema diri (self schema) yaitu pengetahuan tentang diri, yang memengaruhi cara seseorang mengolah informasi dan mengambilkan tindakan (Sarwono \& Meinarno, 2014: 78). Menurut Slameto konsep diri adalah serangkaian kesimpulan yang diambil seseorang tentang dirinya berdasarkan pengalaman, baik secara langsung maupun secara tidak langsung. Secara langsung misalnya, seoranga anak mengetahui bahwa ialah yang terkuat (secara fisik) diantara teman-temannya sekolah, sebab dalam perlombaan dan pertandingan yang memerlukan kekuatan fisik, ia selalu unggul. Secara tidak langsung misalnya, guru selalu mengatakan bahwa si B lemah dalam Matematika. B menerima konsep itu sebagai konsep yang dapat dipercaya dan ia menambahkan,, gelar" itu pada konsep dirinya dengan berkata: "saya tidak begitu pandai dalam Matematika.

Remaja, yang dalam bahasa aslinya disebut adolescence, berasal dari bahasa Latin adolescare yang artinya "tumbuh atau tumbuh untuk mencapai kematangan". Bangsa primitif dan orang-orang purbakala memandang masa puber dan masa remaja tidak berbeda dengan periode lain dalam rentang kehidupan. Anak dianggap sudah dewasa apabila sudah mampu mengadakan reproduksi (Ali \& Asrori, 2016: 32). Remaja merupakan masa dimana peralihan dari masa anak-anak ke masa dewasa, yang telah meliputi semua perkembangan yang dialami sebagai persiapan memasuki masa dewasa. Perubahan perkembangan tersebut meliputi aspek fisik, psikis dan psikososial. Masa remaja merupakan salah satu periode dari perkembangan manusia. Remaja ialah masa perubahan atau peralihan dari anak-anak ke masa dewasa yang meliputi perubahan biologis, perubahan psikologis, dan perubahan sosial (Sofia \& Adiyanti, 2015: 27). Masa remaja adalah masa transisi yang ditandai oleh adanya perubahan fisik, emosi dan psikis. Masa remaja, yakni antara usia 10-19 tahun, adalah suatu periode masa pematangan organ reproduksi manusia, dan sering disebut masa pubertas. Masa remaja adalah periode peralihan dari masa anak ke masa dewasa (Widyastuti, Rahmawati, Purnamaningrum; 2017: 76).

Menurut Slamet Santoso (2018: 79) interaksi dengan teman sebaya merupakan permulaan hubungan persahabatan yang di dalamnya terdapat hubungan timbal balik. Teman sebaya dalam Kamus Besar Bahasa Indonesia diartikan sebagai "kawan, sahabat atau orang yang sama-sama bekerja dan berbuat." Slamet Santosa berpendapat bahwa teman sebaya merupakan kelompok anak sebaya yang sukses ketika anggotanya dapat berinteraksi. Hal-hal yang dialami oleh anak-anak tersebut 
sebagai hal yang menyenangkan saja. Sedangkan Menurut Santrock J. Santrock (2018: 268) teman sebaya adalah anak-anak yang tingkat usia dan kematangannya kurang lebih sama. Hurlock (2018: 288) mengartikan teman sebaya sebagai anak yang memiliki usia dan taraf perkembangan yang sama. Beberapa pengertian teman sebaya di atas dapat disimpulkan bahwa teman sebaya merupakan interaksi pada anak-anak dengan tingkat usia yang sama serta mempunyai tingkat keakraban yang relatif tinggi diantara kelompoknya. Pada teman sebaya biasanya individu mendapat dukungan sosial. Dukungan tersebut dapat mengacu pada kesenangan.

\section{METODE PENELITIAN}

Jenis penelitian yang digunakan dalam penelitian ini adalah penelitian yang disajikan secara deskritif kualitatif. Bodgan dan Taylor (2001:21-22) dalam buku Basrowi dan Suwandi (2008: 09) meyatakan bahwa penelitian kualitatif adalah salah satu prosedur penelitian yang menghasilkan data deskriptif yang berupa ucapan atau tulisan dan perilaku orang-orang yang diamati. Menurut Sugiyono (2012: 7-8) Penelitian kualitatif adalah penelitian tentang riset yang bersifat deskriptif dan cenderung menggunakan analisis. Proses dan makna (perspektif subyek) lebih ditonjolkan dalam penelitian kualitatif. Landasan teori dimanfaatkan sebagai pemandu agar fokus penelitian sesuai dengan fakta di lapangan. Selain itu landasan teori juga bermanfaat untuk memberikan gambaran umum tentang latar penelitian dan sebagai bahan pembahasan hasil penelitian.

\section{HASIL DAN PEMBAHASAN}

\section{Hasil dan Pembahasan}

Self Appraisal-Viewing Self as an Object. Istilah ini menunjukkan suatu pandangan yang menjadikan diri sendiri sebagai objek dalam komunikasi, atau pandangan seseorang tentang dirinya sendiri. Jika seseorang merasakan sesuatu yang tidak disukai tentang dirinya, maka ia akan berusaha untuk mengubahnya. Namun, jika tidak ada kemauan untuk mengubahnya, maka hal ini dapat membentuk konsep diri yang negatif pada diri sendiri. Jadi, semakin besar pengalaman positif yang dimiliki seseorang, semakin positif pula konsep dirinya. Sebaliknya, semakin besar pengalaman negative yang diperoleh seseorang, semakin negatif pula konsep diri yang dimiliki. Berdasarkan penjelasan dari teori tersebut, penulis melakukan wawancara terhadap informan. Berikut hasil wawancara dengan informan kunci yaitu bapak Baihaqi selaku kepala desa Kertapati Mudik dengan pernyataan tentang pandangan bapak/ibu melihat remaja yang menikah muda.

"Di desa kami jarang sekali pemuda yang ingin menikah mempertimbangkan usia, jika mereka sudah berkomitmen untuk menikah mereka akan langsung menikah tanpa memperhitungkan usia, jadi menurut saya remaja yang menikah muda masih terlalu cepat untuk membina rumah tangga, mereka terlalu berani mengambil resiko" (wawancara, 2 maret 2021).

Selanjutnya hasil wawancara dengan bapak Mahari selaku ketua BMA menerangkan bahwa:

"Yang saya lihat kalo ada anak remaja yang ingin menikah mereka biasanya tidak bisa diberi tahu, misalnya keluarga minta untuk di tunda 2 tahun, biasanya mereka kalo sudah ada ucapan untuk menikah ya mereka akan langsung menikah, jika di tunda mereka akan lebih nekad lagi, jadi sebagai perangkat adat kalo ada remaja yang sudah 
ada niat untuk menikah maka kami akan segera urus, agar tidak terjadi hal-hal yang tidak diinginkan" (wawancara, 3 maret 2021).

Berdasarkan hasil wawancara diatas dapat disimpulkan bahwa jika ada remaja yang ingin menikah muda biasanya mereka akan segera melangsungkan pernikahan. Berikutnya penulis melakukan wawancara dengan pernyataan tentang pendapat bapak/ibu terhadap sikap remaja setelah dia menikah. Hasil wawancara dengan bapak Baihaqi yang mengatakan bahwa:

"menurut apa yang saya lihat dan yang saya dengar, sikap remaja setelah mereka menikah ada yang berubah menjadi lebih baik, artinya mereka menyadari bahwa mereka bukan remaja bujang/gadis lagi, tapi mereka sudah menikah. Jadi sikap mereka lebih dewasa dari usianya. Tapi ada juga beberapa remaja yang setelah menikah mereka tidak berubah, misalnya masih sering nongkrong dengan teman-temannya, pergi dengan teman-temannya, tapi hanya beberapa saja" (wawancara, 02 maret 2021).

Reactions and Respons of Others yaitu konsep diri yang berkembang melalui interaksi seseorang dengan masyarakat. Dalam hal ini, konsep diri dipengaruhi oleh reaksi serta respons orang lain terhadap diri kita. Berdasarkan hal tersebut maka penulis jabarkan dalam bentuk beberapa pertanyaan yang disampaikan kepada informan. Berikut hasil wawacara penulis dengan informan berkenaan dengan Reactions and Respons of Others (Reaksi dan Respons Orang Lain).

Hasil wawancara pertama dengan informan kunci yaitu bapak kepala desa dan bapak ketua BMA. Adapun pernyataan pertama dari tanggapan bapak/ibu terhadap pergaulan remaja tersebut selama pasangan menikah muda berinteraksi dengan masyarakat. Berikut hasil wawancara dengan bapak Baihaqi selaku kepala desa mengatakan:

"menurut saya remaja yang menikah muda masih perlu dibimbing dalam pergaulan, baik itu cara berinteraksi maupun bertingkahlaku sehari-hari, karena ada yang menikah muda memang mereka sudah merasa siap tapi ada juga yang mendadak menikah/nekad" (wawancara, 2 maret 2021).

Selanjutnya akan diperjelas oleh hasil wawanacara dengan bapak Mahari selaku ketua BMA, beliau mengatakan:

"kalo yang saya lihat, anak remaja masih sangat minim pengalaman dalam hal bersosialisasi atau berinteraksi, karena mereka mungkin masih harus menyesuaikan status mereka yang tadi bujang/gadis sekarang menjadi suami/istri dimana pergaulan antara masih bunjang/gadis berbeda dengan setelah menikah, jadi masih perlu dibimbing, diberitahu dan diajak untuk ikut dalam kegiatan-kegiatan sosial seperti gotong royong, acara keramaian dan lain-lain" (wawancara, 03 maret 2021).

\section{KESIMPULAN DAN SARAN}

\section{Kesimpulan}

Kesiapan remaja untuk memutuskan menikah diusia muda dapat dikatakan konsep diri negatif karena remaja yang menikah muda didasarkan atas keinginan mereka sendiri tanpa mendengarkan saran dari orang tua dan keluarganya. Namun bagi remaja yang menikah muda dan dapat mempertanggungjawabkan pernikahannya seperti remaja yang menikah muda juga sudah mulai mencari nafkah. Namun setelah adanya perubahan sikap bertanggung jawab terhadap peran masing-masing, dan seperti menganggap mereka mampu menjalani kehidupan rumah tangga mereka, maka konsep diri pasangan menikah muda ini menjadi konsep diri yang positif. Konsep diri pasangan 
menikah muda dapat terbentuk dan berkembang melalui pengalaman, pandangan dan berkembang melalui pengalaman, pandangan, rekasi dan respon dari orang lain dan perilaku sendiri. Reaksi dan respon dari orang lain seperti orang tua, teman sebaya, tetangga dan lingkungan masyarakat disekitarnya. Konsep diri Pasangan remaja yang menikah muda berusaha menjalankan perannya masing-masing. Setelah menikah pasangan remaja berusaha membatasi beberapa hal yang dapat membuat pasangan remaja tidak mengalami permasalahan dalam rumah tangga.. Remaja yang sudah menikah sudah memahami peran mereka masing-masing. Seperti mencari nafkah, mengurus rumah tangga. Hal ini juga tidak lepas dari peran orang tua, kades, BMA, tetangga lingkungan sekitarnya. Namun tidak semua pasangan yang menikah muda dapat menerima keadaan dan perubahan yang terjadi pada dirinya, sehingga 
mengakibatkan timbulnya konsep diri positif dan konsep diri negative yang dikarenakan belum bisa menyesuaikan diri sebelum dan setelah mereka menikah.

\section{Saran}

1. Bagi bapak kepala desa agar lebih memperhatikan keadaan masyarakat untuk dapat menyadari pentingnya pendidikan agar mengurangi remaja yang menikah usia muda

2. Untuk bapak ketua BMA agar dapat memberi sanksi tegas jika terdapat pernikahan dini yang disebabkan seperti hamil diluar nikah, supaya ada efek jera untuk kebaikan remaja berikutnya

3. Untuk orang tua sebaiknya sejak dini menumbuhkan kesadaran anak akan pentingnya pendidikan dan karir

4. Bagi remaja sebaiknya mengurangi hubungan dengan lawan jenis dan untuk lebih fokus ke pendidikan terlebih dahulu baru memutuskan untuk menikah supaya ada bekal untuk kehidupan berumah tangga nantinya.

\section{DAFTAR PUSTAKA}

Acocella, Calhoun. 2015. SELF. Jakarta: Erlangga

Adiyanto, Sofia. 2015. Psikologi Perkembangan Remaja Hingga Dewasa. Raja grafindo persada Jakarta.

Ashori, Ali. 2016. Psikologi perkembangan pendekatan ekologi kaitannya dengan konsep diri, Bandung : PT.Refika Aditama.

Brooks, William. 2017. Interpersonal Communication. Bandung : Pustaka setia.

Burns, R.B. 1993. Konsep diri: Teori, Pengukuran, Perkembangan, Dan Perilaku. Penerjemah Eddy. Jakarta: Arcan.

Calhoun, J.F., dan Acocella, J.R. 1995. Psikologi tentang penyesuaian dan hubungan kemanusiaan. Alih bahasa: R.S. Satmoko Ikip Semarang Press Semarang.

Chaplin, J.P. 2000 kamus lengkap psikologi. Alih bahasa: Raja grafindo persada Jakarta.

Data BKKBN Provinsi Bengkulu Tahun 2019

Devito, A Joseph. 2011. Komunikasi Interpersonal. Jakarta: Erlangga.

Departemen Sosial RI. 2001. Intervensi psikososial. Departemen Sosial Republik Indonesia. Jakarta

Djaali. 2009. Konsep Diri Remaja Awal. Jakarta: Erlangga.

Elizabeth Huclock. 1978. Perkembangan Anak Edisi 11 Jilid 1. Jakarta.

1999. Psikologi Perkembangan: Suatu

sepanjamg rentang kehidupan. Ed. 5. Jakarta: Erlangga.

J. Santrock. 2018. Masa Perkembangan Anak Jilid 1. Jakarta. Salemba Humanika

Gunarsa. 1989. Psikologi Remaja. Jakarta. Salemba Humanika

Mienarno, Sarwono. 2011. Psikologi Perkembangan. grafindo persada Jakarta

Heyes, Hardy. 2018. Tumbuh kembang remaja dan permasalahannya. Jakarta: Sagung seto.

Hidayat. 2000. Keluarga dan Lingkungan. Bandung : Pustaka setia.

Rakhmat, J. 2004. Psikologi komunikasi. Bandung : PT Remaja Rosdakarya.

Rahmawati. 2017. Psikologi Remaja. Jakarta. PT Bumi Aksara 